\title{
Psychological Problems and Quality of Life among Patients Undergoing Heart Procedures
}

\section{Mohamed Khaled Abd Elfattah Elkady ${ }^{1}$, Sayeda Ahmed Abdellatif ${ }^{2}$ and Mona Mohamed Barakat $^{3}$}

(1) Demonstrator of Psychiatric and Mental Health Nursing, Faculty of Nursing, Sohage University, Egypt.(2) Professor of Psychiatric and Mental Health Nursing, Faculty of Nursing, Cairo University, Egypt. (3) Assistant Professor of Psychiatric and Mental Health Nursing, Faculty of Nursing, Benha University, Egypt.

\begin{abstract}
Background: Heart surgery and Coronary catheterization are improved the medical management of cardiac diseases, which, causes a stress, anxiety and depression for patients. All these factors affect patient's quality of life before heart procedures. Aim of the study: This study aimed to assess the psychological problems and quality of life among patient undergoing heart procedures. Research Design: A descriptive design was utilized in this study. Setting: The study was conducted at cardiac department and cardiac catheter unit at Benha university hospital in Benha city, Kaluobia Governorate. Sample: A convenience sample consisting of 100 patients undergoing heart procedures. Tools of data collection: In this study three tools were used for data collection: I) A structured interviewing questionnaire included socio-demographic data and clinical data. II) Depression, Anxiety and Stress Scale (DASS-21) and III) Quality of Life Scale (QOLS). Results: Less than half of the studied patients had mild depression. Furthermore, less than half of the studied patients had extremely severe anxiety, less than one third of patients had severe stress. More than half of the studied patients had moderate level of quality of life and less than half of patients had low of quality of life. Also, there was highly statistically significant negative correlation between total depression, anxiety, and stress and total quality of life among the studied patients. Conclusion: Patients who are undergoing heart procedures are more prone to have psychological problems such as: Depression, anxiety and stress and moderate level of quality of life, where patients who have psychological problems are likely to have impair quality of life. Recommendations: Psychoeducational programs should be integrated as nursing intervention for patients before surgery to enhance their psychological well-being and quality of life. Liaison psychiatric nurse must be available to deal with psychiatric problems of those patients.
\end{abstract}

Key words: Heart procedures, Psychological problems, Quality of life.

\section{Introduction}

Cardiovascular Disease (CVD) is a group of diseases that include the heart and blood vessels, thereby including Coronary Heart Disease (CHD) and Coronary Artery Disease (CAD), and Acute Coronary Syndrome (ACS). ACS is a subcategory of $\mathrm{CAD}$, whilst $\mathrm{CHD}$ results of CAD. On the other hand, CAD is characterized by atherosclerosis in coronary arteries and can be asymptomatic, whereas ACS always presents with a symptom, such as unstable angina, and is frequently associated with Myocardial Infarction (MI) regardless of the presence of CAD. Finally, CAD is usually used to refer to the pathologic process affecting the coronary arteries (usually atherosclerosis) whilst CHD includes the diagnoses of angina pectoris, MI and silent myocardial ischemia (Rashad, 2020). 
Heart procedure, is surgery on the heart or great vessels performed by cardiac surgeons. It is often used to treat complications of ischemic heart disease (for example, with coronary artery bypass grafting); to correct congenital heart disease; or to treat valvular heart disease from various causes, including endocarditis, rheumatic heart disease, and atherosclerosis, it also includes heart transplantation (Tapiero et al., 2017).

Heart surgery is like any other type of surgical procedure for a stressful patient and anxiety and depression are common and important disorders in these patients and these feelings may cause prolonged recovery and compromise quality of life following the surgery. After CABG, patients often report pain, discomfort, feelings of depression, lack of patience, loss of general well-being, and inability to function (Moghtader et al., 2018). Coronary catheterization can be a stressful experience and causes anxiety symptoms for many patients because of its invasive nature and potential risks (Mohammed et al., 2019).

The World Health Organization (WHO) defined health as physical, mental and social well-being. Quality of life implies the ability of people to function normally every day and to be satisfied with their participation in everyday activities. The ability of maintaining these daily activities includes maintaining physical mobility, independence from others, sufficient energy for self-help, social contacts, emotional stability, absence of pain or other symptoms of discomfort, and adequate sleep and rest. Heart surgery and cardiac catheterization are an important surgical procedure for patients with coronary artery disease, which improves the symptoms, survival and quality of life. Unfortunately, patients' quality of life after heart procedures is not improved in all domains, and some patients even experience poorer HealthRelated Quality Of Life (HRQOL) after the surgery (Pačarić et al., 2020).

Nurses caring the patients undergoing heart procedures in the pre-operative period often notice the overwhelming anxiety, fear, depression and stress that many of their patients experience. Information on how these patients experience anxiety, depression and stress before heart surgery is important in order to plan some effective interventions that can be applied and may aid patients to decrease their anxiety, depression and stress levels, resulting in a faster recovery potentially. The findings of this study will also provide additional evidence about preoperative anxiety, depression and stress to the nurses and health professionals in creating health care policies and to implement appropriate interventions (Ramesha et al., 2018).

\section{Significance of the study}

Heart disease is responsible for more than $30 \%$ of deaths worldwide each year (Zambrano et al., 2020). Development of new treatments such as thrombolytic therapy, and international procedures such as percutaneous trans-luminal angioplasty, coronary bypass and valve replacements had improved the medical management of cardiac diseases (Silva \& Ferreira, 2016). Symptoms of anxiety, stress, depression, and pain are usual disturbances in patients with CAD, including those undergoing the heart surgery. Anxiety and depressive symptoms occurred in $30 \%$ and $18 \%$ respectively of patients before heart surgery. All these factors aggravate the symptoms of the prevailing disease, affect physiological parameters adversely before and during anesthesia, and these feelings can seriously impair the patient's quality of life (Zolfaghari et al., 2018). 
These psychological problems negatively affect patient's outcomes as well as quality of life. However, there is a paucity of research in this area in our community of patients. Since, the psychiatric nurse has pivotal role in caring and supporting those patients, accordingly it was deemed necessary to evaluate psychological problems and quality of life among patients undergoing heart procedures.

\section{Aim of the study}

This study aimed to assess the psychological problems and quality of life among patient undergoing heart procedures.

\section{Research Questions}

1. What are the psychological problems among the patients undergoing heart procedures?

2.What is the level of quality of life among patients undergoing heart procedures?

3. What is a relation between psychological problems and quality of life among patients undergoing heart procedures?

\section{Subject and methods}

Research design:

A descriptive design was utilized in this study.

Setting:

The study was conducted at cardiac department, cardiac catheter unit at Benha university hospital in Benha city, Kaluobia Governorate, which is affiliated to ministry of higher education. The cardiac catheter unit includes three sections: first section for male patients, the capacity of this is 12 beds and second section for female have 4 beds and third section for female have 12 beds. The cardiothoracic department includes two rooms; one for male have 4 beds and another room for female have for bed.

\section{Sampling:}

A convenience sample consisting of 100 patients undergoing heart surgery in cardiac department and cardiac catheter unit at Benha university hospital who fulfilled the following criteria: All available patients in department, both sexes, agreement to participate in the study and free from psychiatric disorders.

\section{Tools of data collection}

In order to achieve the aim of the study the following tools were being used:

\section{Tool 1: A structured Interview Questionnaire Sheet:}

Structured interview questionnaire was developed by researchers based on scientific review of literature which consist of two parts:

- Part I: Socio-demographic data as age, sex, education level, marital status.

- Part II: Clinical data as age at the onset of the disease, number of times of hospitalization.

Tool 2: Depression, Anxiety and Stress Scale (DASS-21):

This scale developed by Lovibond \& Lovibond, (1995). It set of three self-report scales design to measure the emotional states of depression, anxiety and stress. Each of three DASS-21 as scales contains 7 items, the rating scale from (0 to3) as follows: (0) did not apply to me at all,(1) applied to me some degree or some of the time,(2) applied to me to considerable degree or a good part of time,(3) applied to me very much or most of the time. The total equal 63 points and the higher the score the worst the DASS.

\section{Scoring system of DASS}

1.Depression: normal 0-9, mild 10-13, moderate 14-20, sever 21-27, extremely sever 28 and more.

2.Anxiety: normal 0-7, mild 8-9, moderate 10-14, sever15-19, extremely sever 20 and more.

3.Stress: normal 0-14, mild 15-18, moderate 19-25, sever 26-33, extremely sever 34 and more. 


\section{Tool 3:- Quality of Life Scale (QOLS)}

This scale developed by Lehman, (1986) to assess QOL of patient. It consists of (57) items divided into six domains or subscales, include: - physical health that comprising 12 items, self-care that consisted of 8 items, emotional status that included 14 items, personal \&social relationship that consisted of 13 items, self-reliance included 5 items, spiritual concerns and personal beliefs that consisted of 5 items. The rating scale from (0 to 2) as follows: (0) Always, (1) Sometimes, (2) Never. The total score was 114 points.

\section{Scoring system of Quality of Life Scale (QOLS)}

The total score was 114 points. Individual obtained a score less than 57 points were considered to have a low quality of life, while those who scored between 57-85 points were considered to have a moderate quality of life, and finally, those who scored more than 85 points were considered to have a high quality of life.

\section{Content validity and Reliability:}

The developed tool was reviewed for appropriateness of items and measuring the concepts through 5 experts in psychiatric \& mental health nursing and medicine specialists to assure content validity and modification was done accordingly. The study tools were tested for its internal consistency by Cronbach's Alpha. Reliability of DASS is 91, while QOL scale is 83.

\section{Ethical considerations}

Approaches to ensure the ethical issues were considered in the study regarding confidentiality and informed consent. Confidentiality was achieved by the use of locked sheets without names of the participants and replaced by numbers. All the participants were informed that the information they provided during the study would be kept confidential and used only for statistical purpose and after finishing the study. Each patient was informed that participation in the study was voluntary, and had the right to withdraw from the study at any time.

\section{Pilot study}

A pilot study conducted to test the applicability of the instruments, the feasibility of the study and estimate the time needed for collecting the data. It was conducted on $10 \%$ of the total sample (10 patients) according to the selection criteria. All patients participated in the pilot study excluded from the study sample because the researcher rephrased some questions and sentences then set the final fieldwork schedule.

\section{Field work:}

1.The After appraisal of the protocol of the study for ethical and scientific committee an official permission letters obtained from the dean of the Faculty of Nursing, Benha University and official permission was obtained from the director of Benha University hospital to conduct the proposed study.

2.The purpose of the study was simply explained to the patients who agree to participate in the study prior to any data collection.

3.Each participant interviewed and assessed individually.

4.Each patient was handed the questionnaire and answered it under observation of the researcher. Patient who can't read well, the researcher help them to record their answers.

5.The first instrument (Depression, Anxiety and Stress Scale) filled in about 20-25 minutes and the second instrument (Quality of Life Scale) filled in about 2530 minutes.

6. The process of data collection occurred 2 days per week and took about 10 months 
started in 10 October 2019 and ended in 20 august 2020 .

\section{Statistical analysis}

Data Upon completion of data collection, the collected data were organized, tabulated; statistically analyzed by using an IBM personal computer with Statistical Package of Social Science (SPSS) version 22. Data were presented using descriptive statistics in form of number and percentage, mean, standard division, and Qualitative variables were comparing using the chisquare test. For quantitative data, person correlation coefficient ( $r$ ) was used for correlation analysis and degree of significance was identified. A statistically significant difference was considered if $p$-value was< 0.05. A highly statistically significant difference was considered if $\mathrm{p}$-value was $<$ 0.001 .

\section{Results}

Table (1): Reveals that more than half $(54 \%)$ of the studied patient's age ranging between $40-<50$ years with Mean \pm SD $(43 \pm$ $6.86)$, less than two thirds $(65 \%)$ of them were male. more than three quarters $(78 \%)$ of patients were married, more than one third $(36 \%)$ of them had university education. Less than half $(49 \%)$ of patients were not working, majority of them $(88 \%)$ were living with their family, and majority (82\%) of them lived in rural.

Table (2): Reveals that less than half $(43 \%)$ of the studied patients had 40 years and more regarding their age at the onset of the disease, less than half (49\%) of them had 1-3 times regarding number of times of hospitalization, three quarters $(75 \%)$ of them had 1-<5 years of disease duration. Also, more than half $(56 \%)$ of patients suffered from chronic disease, and more than half $(53 \%)$ of them had open heart surgical operation.
Figure (1): Shows that less than half (40\%) of the studied patients had mild depression and one fifth $(21 \%)$ of patients had extremely severe depression. And this figure shows that less than half $(41 \%)$ of the studied patients had extremely severe anxiety, minority $(6 \%)$ of them had sever condition, also more than one third (37\%) of them had moderate anxiety. Regarding level of stress this Figure shows that less than one third $(31 \%)$ of the studied patients had normal stress level while, less than one third (28\%) of patients had severe stress.

Figure (2): Shows that that more than half $(59 \%)$ of the studied patients had moderate level of quality of life and less than half $(41 \%)$ of patients had low of quality of life. While, no one of patients had high of quality of life

Table (3): Illustrates that, there was a highly statistically negative significant correlation between patients' depression, anxiety and stress subscales and personal care, religious traditions and personal beliefs subscales at p-value <0.01.Also, there was a statistically significant negative correlation between patients' DAS subscales and physical status, emotional status, social and personal relations, and self-reliance subscales at $\mathrm{p}$ value $<0.05$.

Table (4): Show that, there was highly statistically significant negative correlation between total depression, anxiety, and stress and total quality of life among the studied patients at $\mathrm{P}$-value $=<0.001$. 
Table (1): Percentage of socio-demographic characteristics of the studied patients $(n=100)$.

\begin{tabular}{|c|c|c|}
\hline Socio-demographic characteristics & No. & $\%$ \\
\hline Age (years) & & \\
\hline$-\quad 20-<30$ year & 5 & 5 \\
\hline $30-<40$ year & 7 & 7 \\
\hline $40-<50$ year & 54 & 54 \\
\hline 50 years and more & 34 & 34 \\
\hline Mean \pm SD & $43 \pm 6.86$ & \\
\hline Sex & & \\
\hline Male & 65 & 65 \\
\hline - $\quad$ Female & 35 & 35 \\
\hline Marital status & & \\
\hline$-\quad$ Single & 7 & 7 \\
\hline Married & 78 & 78 \\
\hline Widowed & 10 & 10 \\
\hline Divorced & 5 & 5 \\
\hline Educational level & & \\
\hline - $\quad$ Illiterate & 26 & 26 \\
\hline Basic education & 13 & 13 \\
\hline Secondary education & 25 & 25 \\
\hline - $\quad$ University education & 36 & 36 \\
\hline Occupation & & \\
\hline - Employee & 35 & 35 \\
\hline Free worker & 16 & 16 \\
\hline - $\quad$ Not working & 49 & 49 \\
\hline Cohabitation & & \\
\hline - $\quad$ Alone & 4 & 4 \\
\hline With family & 88 & 88 \\
\hline - $\quad$ With his relatives & 8 & 8 \\
\hline Residence & & \\
\hline - $\quad$ Rural & 82 & 82 \\
\hline Urban & 18 & 18 \\
\hline
\end{tabular}

Table 2: Percentage of the studied patients according to their clinical data $(n=100)$.

Clinical data
Age at the onset of the disease (years).

- $\quad 20-<30$ year

No.

\section{$\%$}

$16 \quad 16$

- $\quad 30-<40$ year

41

43

41

- $\quad \geq 40$ years

Number of times of hospitalization

- 1-3 times

- 4-6 times

- $\quad \geq 7$ times

Disease duration

- $\quad 1-<5$ years

- $\quad 5-<10$ years

- $10-<15$ years

Presence of chronic disease

- Yes

$5 \quad 5$

- No

56

5

Type of surgical operation

$\begin{array}{ll}\text { - } & \text { Open heart } \\ \text { - } \quad \text { Cardiac catheterization }\end{array}$

$44 \quad 44$




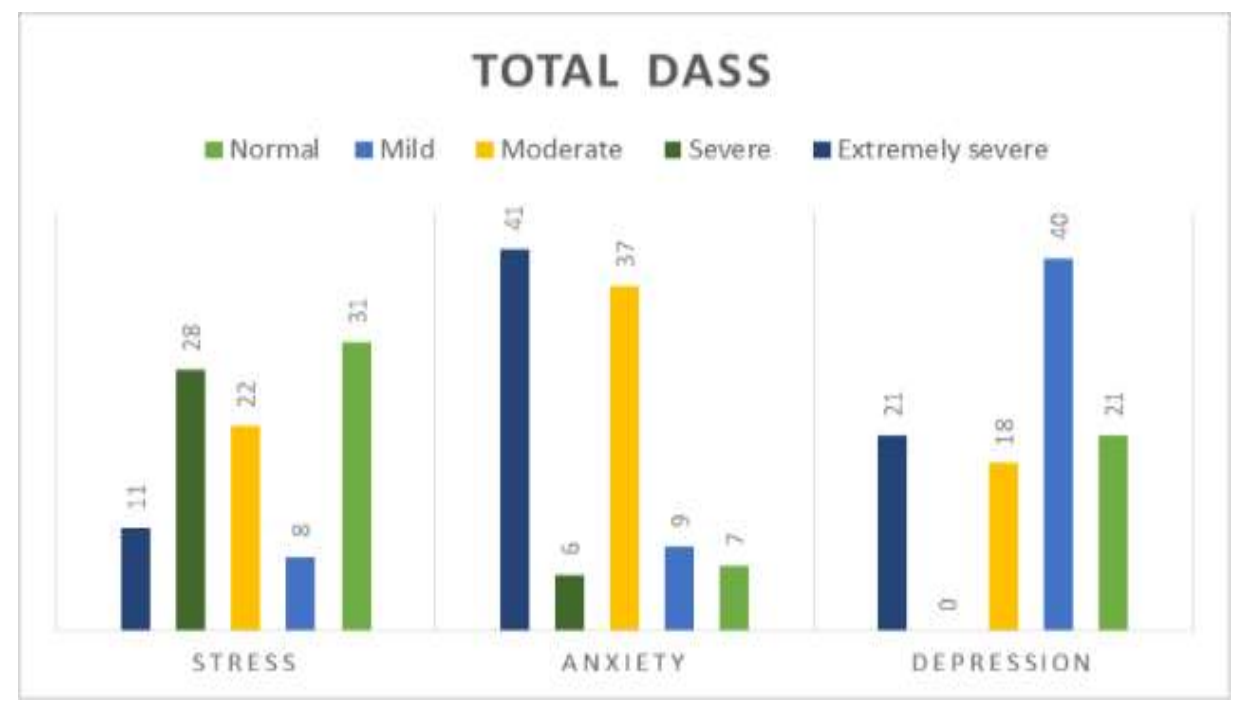

Figure (1): Percentage of total level of depression, anxiety and stress among the studied patients $(\mathbf{n}=100)$.

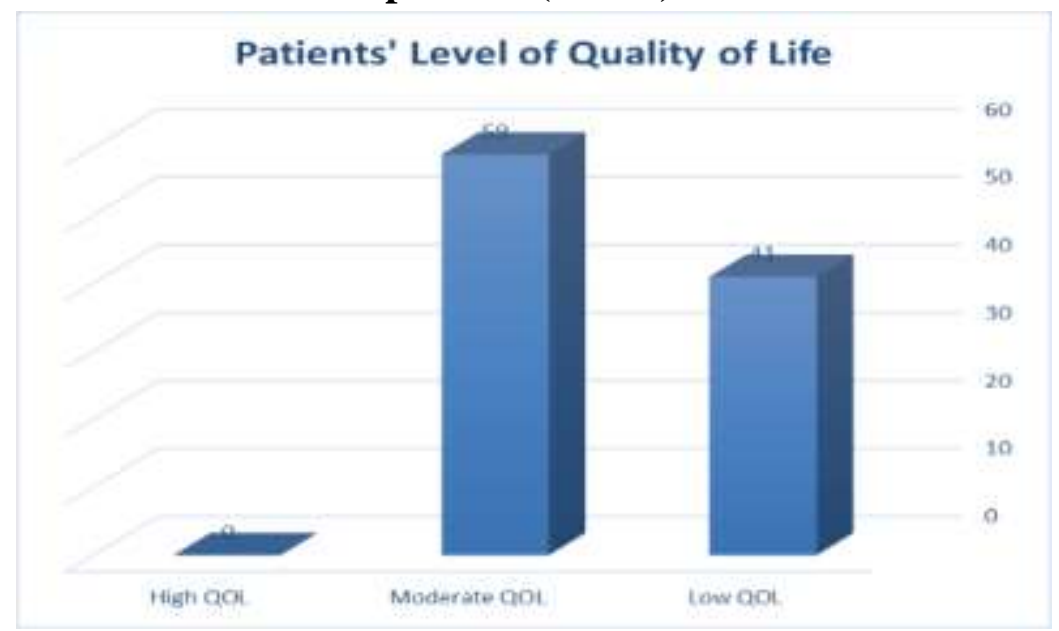

Figure (2): Percentage of patients' total quality of life $(n=100)$.

Table (3): Correlation between total quality of life subscales and depression, anxiety, stress subscales among the studied patients $(n=100)$.

\begin{tabular}{|c|c|c|c|c|}
\hline \multirow{2}{*}{\multicolumn{2}{|c|}{ Quality of life subscales }} & \multicolumn{3}{|c|}{ DAS Subscales } \\
\hline & & $\begin{array}{l}\text { Depression } \\
\text { subscale }\end{array}$ & Anxiety & Stress \\
\hline \multirow[t]{2}{*}{ Physical status subscale } & $\mathrm{r}$ & -.303 & -.341 & -.154 \\
\hline & $\mathrm{P}$ & $.002 *$ & $.001 *$ & -.154 \\
\hline \multirow[t]{2}{*}{ Personal care subscale } & $\mathrm{r}$ & -.614 & -.538 & -.684 \\
\hline & $\mathrm{P}$ & $.000 * *$ & $.000 * *$ & $.000 * *$ \\
\hline \multirow[t]{2}{*}{ Emotional status subscale } & $\mathrm{r}$ & -.244 & -.211 & -.204 \\
\hline & $\mathrm{P}$ & $.006 *$ & $.013 *$ & $.041 *$ \\
\hline \multirow{4}{*}{$\begin{array}{l}\text { Social and personal relations } \\
\text { subscale } \\
\text { Self-reliance subscale }\end{array}$} & $\mathrm{r}$ & -.279 & -.281 & -.216 \\
\hline & $\mathrm{P}$ & $.005 *$ & $.004 *$ & $.029 *$ \\
\hline & $\mathrm{r}$ & -.242 & -.312 & -.205 \\
\hline & $\mathrm{P}$ & $.015^{*}$ & $.002 *$ & $.041 *$ \\
\hline \multirow{2}{*}{$\begin{array}{l}\text { Religious traditions and } \\
\text { personal beliefs subscale }\end{array}$} & $\mathrm{r}$ & -.454 & -.332 & -.653 \\
\hline & $\mathrm{P}$ & $.000 * *$ & $.000 * *$ & $.000 * *$ \\
\hline
\end{tabular}


Table (4): Correlation between total quality of life and total depression, anxiety, and stress subscale among the studied patients $(n=100)$.

\begin{tabular}{lll} 
& & Quality of life scale \\
DAS scale & $\mathrm{R}$ & $\mathrm{P}$ \\
Depression & -.661 & $.000^{* *}$ \\
Anxiety & -.483 & $.000^{* *}$ \\
Stress & -.697 & $.000^{* *}$ \\
\hline
\end{tabular}

\section{Discussion}

Psychological problems are common before cardiac surgery, Technical advances; heart surgery remains a major adaptive challenge, especially for the increasing number of older and otherwise more vulnerable heart surgery patients. Depression is recognized as being associated with physical illness, and is particularly prevalent in patients with heart disease. Anxiety may reflect forms of psychosocial vulnerability during the period preceding surgery. Stress also can affect direct on physiological response to a medical illness and hospitalization and have been documented to significantly increase in the first month after surgery ((Murphy, et al., 2020)). So, the current study aimed to assess the psychological problems and quality of life among patient undergoing heart procedures.

Regarding the socio-demographic characteristics of the studied patients, the current study result showed that, more than half of the studied patients their age ranging between $40-<50$ years, less than two thirds of them were male. more than three quarters of patients were married, more than one third of them had university education. Less than half of patients were not working, majority of them were living with their family, and majority of them lived in rural.

Regarding total level of depression among the studied patients, the current study showed that less than half of the studied patients had mild depression and one fifth of them had extremely severe depression. This result may be due to cardiac disease affect negatively on mood of patients before surgery and isolate them from others that consequently affecting depression level. This result is supported with Jackson et al., (2018) who reported that more than one third of patients had mild depression. Conversely, this result is in disagreement with Indja et al., (2017) who revealed that the majority of patients had extremely severe depression.

Regarding to total level of anxiety among the studied patients, the current study showed that less than half of the studied patients had extremely severe anxiety, minority of them had sever condition, also, more than one third had moderate anxiety. This result may be due to patients increasing felling of fear of death, fear of unknown origin, financial loss and results of operation, the waiting time before the surgical operation this feeling caused anxiety before cardiac surgery and obviously affecting patients. This result is accordance with Woolf et al., (2017) who reported that nearly half of patients had extremely severe anxiety. Also, this result is in agreement with Kolaitis et al., (2017) who revealed that more than one third of patients had moderate anxiety.

Regarding to total level of stress among the studied patients, the current study showed that less than one third had severe stress. From the researcher point of view, this result may be due to heart surgery is a Stressful experience threatening all dimensions of life of many patients and health 
conditions of patients before cardiac surgery were unsuitable and effect on their mood. This result is in agreement with, Richards et al., (2017) who stated that, one third of patients had severe stress after heart disease. Conversely, this result is in disagreement with Weinrib et al., (2017) who revealed that more than half of patients had stress before heart procedures.

Regarding to total level of quality of life among the studied patients, the current study illustrated that more than half of the studied patients had moderate level of quality of life and less than half of patients had low of quality of life. From the researcher point of view, this result may be due to before the surgery, patients experience a lot of physical and psychological problems. The symptoms of disease include chest pain, dyspnea, fatigue, inability to perform exercise and physical activity, fear, stress and anxiety and depression. These factors may negatively affect QOL of the patients, cardiac surgery effect on the life of patients that hinder their normal quality of life while some of them can cope adequately with their condition. This result is supported with Backemar et al., (2020) who reported that more than half of patients had moderate level of quality of life. Conversely, this result is supported with Bahall et al., (2020) who found that one quarter of patients had high level of quality of life.

Regarding correlation between total quality of life and their depression, anxiety, and stress among the studied patients, the current study showed that there was highly statistically significant negative correlation between total depression, anxiety, and stress and total quality of life among the studied patients. From the researcher point of view, this result may be due to Anxiety, stress and depressive symptoms, which occurred in substantial percentage of patients undergoing heart procedures. Psychiatric problems had an adverse impact on patients' quality of life. This result is in agreement with, Takemoto et al., (2020) who reported that that there was highly statistically significant negative correlation between total depression, anxiety, and stress and total quality of life among the studied patients. Also, this result is supported with Guzelhan et al., (2020) who shown that a there was highly statistically significant negative correlation between total depression, anxiety, and stress and total quality of life among the studied patients.

\section{Conclusion}

Less than half of the studied patients had mild depression, one fifth of had extremely severe depression. Less than half of the studied patients had extremely severe anxiety; also more than one third of them had moderate anxiety. Furthermore, one third of the studied patients had normal stress level, less than one third of patients had severe stress. Also, more than half of the studied patients had moderate level of quality of life and less than half of patients had low of quality of life. Also, there was highly statistically significant negative correlation between total depression, anxiety, and stress and total quality of life among the studied patients. The study concluded that patients who are undergoing heart procedures are more prone to have psychological problems such as depression, anxiety and stress, which patients who have psychological problems are likely to have impaired quality of life.

\section{Recommendations}

- Psycho-educational programs should be integrated as nursing intervention for patients before surgery to enhance their psychological well-being and quality of life. 
- Supportive groups to help patients and their parents to overcome any psychological problems.

- Routine assessment of patients' psychological status before surgery is recommended to determine which patients are at risk for increased anxiety and depression after surgery.

- Preoperative education should be incorporated into routine practice to prepare cardiac patients for surgery to reduce anxiety and stress.

- Relaxation training program have to be part of treatments program for patients undergoing heart procedures.

- Further studies by using larger probability sample for generalization of the result

\section{References}

Backemar, L., Johar, A., Wikman, A., Zylstra, J., Gossage, J., Davies, A., \& Lagergren, $\mathbf{P}$. (2020). The influence of comorbidity on health-related quality of life before cardiac surgery. Annals of surgical oncology, 27(8), 2637-2645.

Bahall, M., Legall, G., \& Khan, K. (2020). Quality of life among patients with cardiac disease: the impact of comorbid depression. Health and quality of life outcomes, 18(1), 110.

Guzelhan, Y., Ugurlucan, M., Oztas, M., Beyaz, O., Unal, O., Bektas, N., \& Bozbuga, N. (2020). Anxiety and healthrelated quality of life before cardiac surgery. Archives of Medical Science-Atherosclerotic Diseases, 5(1), 27-35.

Indja, B., Seco, M., Seamark, R., Kaplan, J., Bannon, P., Grieve, S., \& Vallely, M. (2017). Neurocognitive and psychiatric issues before cardiac surgery. Heart, Lung and Circulation, 26(8), 779-785.

Jackson, J., Leslie, C., \& Hondorp, S. (2018). Depressive and anxiety symptoms in adult congenital heart disease: Prevalence, health impact and treatment. Progress in cardiovascular diseases, 61(3-4), 294-299.

Kolaitis, G., Meentken, M., \& Utens, E. (2017). Mental health problems in parents of children with congenital heart disease. Frontiers in pediatrics, 5, 102.

Lehman, F. (1986). Quality of Life Scale. Lovibond, P., \& Lovibond, S. (1995). "The structure of negative emotional states: Comparison of the Depression Anxiety Stress Scales (DASS) with the Beck Depression and Anxiety Inventories". Behaviour Research and Therapy.33 (3): 335-343.

Moghtader,A., , Salari, A., Shad B., Hasandokht ,T., \&Nourisaeed, A.,(2018). depression and anxiety in patients undergoing open heart surgery: Age and Sexual Differences Quarterly of the Horizon of Medical Sciences. 24 (3)

Mohammed, A., El-Ashry, M., \&Elganzory, G. (2019). Psychosocial Problems among Patients undergoing Coronary Catheterization. Egyptian Journal of Health Care, 10(1), 80-90.

Murphy, B., Le Grande, M., Alvarenga, M., Worcester, M., \& Jackson, A. (2020). Anxiety and depression before a cardiac event: prevalence and predictors. Frontiers in psychology, 10, 3010.

Pačarić, S., Turk, T., Erić, I., Orkić, Ž., Petek Erić, A., Milostić-Srb, A., Farčić, N., Barać, I., \& Nemčić, A. (2020). Assessment of the quality of life in patients before and after coronary artery bypass grafting (CABG): a prospective study. International journal of environmental research and public health, 17(4), 1417.

Ramesha ,C., Nayaka , S., Vasudev, B., Georgea , A., Georgea , S., \&Devia, S. (2018). Pre-operative anxiety in patients undergoing coronary artery bypass graft surgery - A cross-sectional study International Journal of Africa Nursing Sciences V. 7, Pages 31-36. 
Rashad, M. (2020). Evidence of pre and postoperative care for open heart surgery patient's on physiological and psychological Outcomes. (Helwan university) ,Egypt,P 20.

Richards,H., Anderson, L., Jenkinson, E., Whalley, B., Rees, K., Davies, P., \& Taylor, S. (2017). Psychological interventions for coronary heart disease. Cochrane Database of Systematic Reviews, (4).

Silva, R., \& Ferreira, M. (2016). Technology in an intensive care unit: delineation of a figure-type of the nurse. Acta Paul Enferm., 24(5):617-23.

Takemoto, E., Wolfe, M., Nagel, L., \& Boone-Heinonen, J. (2020). physical and mental health-related quality of life changes among insurer subgroups following cardiac surgery. Obesity, 28(3), 669-675.

Tapiero, H., Ba, G., Couvreur, P., \& Tew, K. (2017). Polyunsaturated fatty acids (PUFA) and eicosanoids in human health and pathologies. Biomedicine \& pharmacotherapy, 56(5).

Weinrib, Z., Azam, A., Birnie, A., Burns, C., Clarke, H., \& Katz, J. (2017). The psychology of cardiac disease surgical pain: new frontiers in risk factor identification, prevention and management. British journal of pain, 11(4), 169-177.

Woolf, E., Anger, A., Arnold, A., Weiss, J., \& Teitel, D. (2017). Mental health among parents of children with critical congenital heart defects: a systematic review. Journal of the American Heart Association, 6(2), e004862.

Zambrano, J., Celano,C, James, L., Christina, N., Chung,W., Rachel, A.(2020). Psychiatric and Psychological Interventions for Depression in Patients With Heart Disease: A Scoping Review. Journal of the American Heart Association. Journal of the American Heart AssociationVol. 9, No. 22.

Zolfaghari, M., Mirhosseini ,S., Baghbeheshti, M., Afshani, A., Moazzam ,S., Golabchi ,A.(2018). Effect of physiotherapy on quality of life after coronary artery bypass graft surgery. J. Res. Med. Sci. 23:56.. 


\section{المشاكل النفسية وجودة الحياة لاي المرضي الخاضعين لعمليات بالقلب}

محمل خالد عبد الفتاح - سيدة أحمد عبد اللطيف - مني محمد عبدالعزيز بركات

تعتبر عمليات القلب إحدى طرق علاج مرضى الثريان التاجي لها ثأثير جسدي ونفسي و عاطفي كبير

على المرضى. وفقًا للار اسات الحديثة، تساهم العوامل النفسية بشكل كبير في النتائج السلبية لجراحة الثريان التاجي. العوامل الرئيسية هي الاكتئاب والقلق والعوامل الثخصية وسمات الثخصية والعزلة الاجتماعية وضغوط الحياة المزمنة. لذا هدفت هذه الدراسة إلى تقييم المشاكل النفسية وجودة الحياة بين المرضى الذين يخضعون لعمليات بالقلب، وقد أجريت هذه الدر اسة على ( . ( ) مريض ممن يخضعون لعمليات بالقلب في قسم القلب ووحدة قسطرة القلب في مستشفى بنها الجامعي ، حيث أوضحت نتائج الدر اسة ان اقل من نصف المرضى الخاضعين للار اسة يعانون من اكتئاب خفيف وخمسهم يعانون من اكتئاب شديد للغاية. فيما يتعلق بمستوى القلق ، اقل من نصف المرضى الذين خضعو اللار اسة يعانون من قلق شديد للغاية ، كما أن من ثلث المرضي يعانون من قلق معتدل. أيضًا فيما يتعلق بمستوى التوتر ، ثلث المرضى الخاضعين للار اسة لديهم مستوى توتر طبيعي بينماقل من ثلث المرضى بعانون من توتر شديد، و أظهرت النتائج ايضا ان اكثر من نصف المرضى الذين خضعو اللار اسة كان لديهم مستوى متوسط من جودة الحياة ، اقل من نصف من المرضى كان لديهم جودة حياة متدنية. ، كما اوصت الدر اسة على دمج بر امج تثقيفيه نفسية كتدخل تمريضي للمرضي قبل الجراحة لتعزيز صحتهم النفسية وجودة الحياة وايضا يجب أن يكون برنامج التدريب على الاسترخاء جزءًا من برنامج العلاج للمرضى الذين يخضعون لإجر اءات القلب. 